УДК 94 (47) 19/20

DOI: $10.24866 / 1998-6785 / 2017-4 / 29-39$

\author{
Гузей Я.С. \\ Guzei Ya.S..
}

\author{
Переселение и захват: практики захватного \\ землепользования на российском Дальнем Востоке \\ во второй половине XIX - начале XX вв.
}

\title{
Colonization and seizure of land: practices of seizure of lands in the Far East of the Russian Empire in the second half of XIX - early XX centuries
}

В статье анализируются практики захватного землепользования на дальневосточной окраине Российской империи во второй половине XIX - начале XX вв. Ставится задача проанализировать, что понималось под «захватным землепользованием» на Дальнем Востоке России во второй половине XIX - начале XX в.

Ключевые слова: зеллепользование, земельный захват, позелельньце отношения, заимки, межевое дело

The article is devoted to analyzing practices of seizure of lands in the Far East of the Russian Empire in the second half of XIX - early XX centuries. The task is to analyze what was understood under the "seizure of lands" in the Far East in the second half of XIX - early XX centuries.

Key words: using land, seizure of lands, land relations, squatter's holding, land surveying

К середине XIX столетия Российская империя оказалась по своим территориальным масштабам крупнейшей страной на политической карте мира. Серия договоров с Китаем, заключённых в 1858-1860 гг., сделала её обладательницей значительных земельных просторов, раскинувшихся на тысячи километров, поставив перед осознанной необходимостью заселения и развития дальневосточного региона.

Тема колонизации дальневосточных земель была и по-прежнему остаётся весьма актуальной в современной исторической науке. Исключительно интересной её делает тот фракт, что на этих, сравнительно поздно присоединённых к империи землях сложилась совершенно особая, отличная от европейской части России, система землеустройства, характеризующаяся значительной свободой пользования землёй и широко распространёнными практиками захватного землепользования. Их

Статья выполнена при финансовой поддержке РГНФ, в рамках проекта: «Институт захватного землепользования на Востоке России: исторический и сравнительный анализ», 1632-00029.

ГУЗЕЙ Яна Сергеевна, к.и.н., преподаватель кафедры «Международные отношения» Санкт-Петербургского политехнического университета Петра Великого. (2. СанктПетербург). E-mail: guzeiana@mail.ru 
наличие и распространение на восточной окраине России активно фиксировалось исследователями $[1 ; 3 ; 10 ; 13 ; 15 ; 20 ; 21 ; 23 ; 24 ; 25]$, но редко становилось предметом отдельного серьёзного анализа [19]. Между тем вопрос о практиках захватного землепользования представляется довольно значимым и актуальным, позволяющим пролить свет на многие аспекты жизни имперской окраины: что понималось под «земельным захватом» на востоке России и можно ли вообще использовать данный термин применительно к территориям российского Дальнего Востока, как эти земельные захваты воспринимались населением и властью.

\section{«Пустынный» Дальний Восток и его заселение}

Присоединение Дальнего Востока поставило российское самодержавие перед необходимостью прочного закрепления присоединённых земель за Россией. Единственным способом решительно закрепить российские права на эти земли было проведение их эффрективной колонизации, посредством переселения в регион тех, кто мог бы их успешно освоить и развить. Исключительно важным элементом в этом отношении оказывался русский крестьянин, способный не только освоить необъятный дальневосточный земельный фронд, но и в перспективе дальнейшего развития превратиться в постоянного жителя российской окраины, закрепив Дальний Восток за Россией не только «на бумаге», но и практически. И если некогда российские земли за Уралом, по меткому замечанию известного российского экономиста А.А. Исаева, лишь «увеличивали блеск московской короны», оставаясь нетронутыми «пустынями», в царской политике позднеимперской России им надлежало играть совершенно особую роль и значение - стать постоянным местом жительства для массы крестьян, отправившихся за счастьем в новые края [7, с. 14].

C момента присоединения к Российской империи, Дальний Восток считался неотъемлемой частью необъятной Сибири, заселение которого было частью общего процесса колонизации отдалённых сибирских земель. Между тем, ввиду политической важности дальневосточных территорий, уже в 1861 г. для них были разработаны особые правила, регулировавшие поселение в новом регионе. Согласно этим правилам, в Амурской и Приморской областях было дозволено селиться всем желающим, как русским, так и иностранцам. Переселенцам предоставлялся в пользование довольно значительный надел - в 100 десятин на семью, широкие льготы в податях и повинностях: переселенцы в Приамурский край на 10 лет освобождались от воинской повинности, навсегда от подушной подати и на 20 лет - от всяких вообще платежей в пользу казны. Что же касается переселявшихся в Южно-Уссурийский край, то для них особыми правилами 1866 г. была установлена ещё и выдача ссуд до 100 рублей на семью и запас продовольствия на год со времени водворения в крае. [9, с. 20].

Такие меры правительства объяснялись прежде всего политической необходимостью скорейшей колонизации Дальнего Востока, которая была призвана закрепить приобретённые территории за Россией и защитить их от посягательств соседнего Китая. Именно эта мысль высказывалась в отчёте Южно-Уссурийского переселенческого управления, отмечавшего, что главной целью правительства в регионе является стремление заселить край «русскими людьми, укоренить в нем русское владычество и дать должный отпор посягательствам Китая, который своею пограничной колонизацией и приготовлениями в Маньчжурии, обнаруживает стремление завладеть выходом к морю этой обширной страны» (РГИА. Ф. 391. Оп. 1. Д. 24. Л. 67 об). И хотя впоследствии правила переселения в регион не раз менялись, между тем, стремление 
правительства создавать благоприятные условия для переселения на Дальний Восток в целом продолжало оставаться неизменным.

Одним из важнейших стимулов привлечения в людей в регион был сравнительно большой размер земельного надела, который в отличие от других областей, здесь можно было получить фрактически "свободно» в постоянное и бессрочное пользование [9, с. 28; 2, с. 53]. И последнее обстоятельство несомненно оказывало значительное влияние на решение людей идти искать лучшей доли на российской окраине.

Учёт переселенцев начался с 1885 г., и, по оценкам специалистов, за период с 1885 по 1903 г. в районы Сибири и Дальнего Востока переселились около 1900000 человек [9, с. 4]. В большинстве своём это были те, кто отправлялся сюда, по образному выражению известного имперского специалиста по вопросам переселения и землепользования А.А. Кауфмана, в «погоню за землёй и счастьем», которые они так и не смогли обрести на родине [9, с. 278]. В переселении они видели возможность решения проблемы собственного малоземелья, с которой в середине XIX столетия столкнулись в большинстве губерний европейской России [См.: 6, 12]. Малонаселённые территории за Уралом в этом смысле представлялись мужицкому воображению в самых радужных красках - в качестве царства бескрайних просторов и нетронутых земель, сулящих их обладателям быстрое обогащение: «земли много, паши сколько душе угодно, цена на хлеб высокая, покосы намерены, разводи скота - сколько знаешь, лес вокруг дворов растёт, рыбы много - не переловить, заработки - хороши и при всем довольствии - повинностей меньше» [11, с. 40]. И отчасти такие представления не были лишены некоторых оснований.

Только на территориях Сибири и Дальнего Востока российский крестьянин получал уникальную возможность самостоятельно выбирать земли, на которых он желал бы водвориться. Это непреложное право закреплялось за переселенцами и особо подчёркивалось царским правительством: «Надел землёю крестьянина составляет для него акт особой важности в европейских губерниях, где вообще каждая дача имеет уже совершенно определённые границы в межах соседних владений, по сему межевание есть только проверка планов. Если надел так важен там, то тем более это важно пахарю здесь, где нестесненный смежными дачами, он вправе и может выбирать желаемые угодья. Поставив усадьбы, переселенец может свободно брать пахотную землю в ту или другую сторону, назначить выгон, указать сенокосы, в местах по своему усмотрению, в пределах установленного очертания дачи и причитающейся обществу площади» (РГИА. Ф. 391. Оп. 1. Д. 24. Л. 66 об-67). Каждая отдельная семья или группа переселенцев в праве была самостоятельно выбрать место «по своему желанию и вкусу», а все фрормальности по водворению ограничивались «подачей прошения о разрешении поселиться на известном, избранном месте или причислиться к известному селению» [11, с. 42].

Содействие переселенцам со стороны чиновников должно было выражаться лишь в указании маршрута и свободных пространств, в пределах которых могло осуществляться водворение новопоселенцев. Между тем, интересно, что переселенцы нередко поступали вопреки решениям местных чиновников и вместо осмотра отведённых им урочищ, выбирали совершенно иные места для поселения. Так, в отчёте Южно-Уссурийского переселенческого управления за 1883 г. особо отмечался «самовольный поступок» группы переселенцев, которые, не дойдя до отведённого им урочища, разбили лагерь и решили самостоятельно искать подходящие места для водворения. Чиновник переселенческого управления был вынужден уступить их желанию, поскольку опасался, что решительные 
меры могли бы «убить в переселенцах сознание свободы выбора земли» и "подсечь в корне их энергию, столь необходимую для устройства их быта» (РГИА. Ф. 391. Оп. 1. Д. 24. Л. 41-41 об). И подобные самовольные поступки переселенцев в отношении земельных богатств края были здесь не исключением, а скорее правилом.

Значительные пространства незанятой земли и фрактическое отсутствие сколько-нибудь серьёзного наблюдения за территорией обширного малонаселённого края открывали перед жителями окраины широкий простор для реализации своей хозяйственной активности, выражавшихся в несогласованных с администрацией региона занятиях свободных земель. Известному агроному Н.А. Крюкову, по поручению генералгубернатора С.М. Духовского проводившему в 1895 г. исследование крестьянского землепользования в Амурской и Приморской областях, пришлось констатировать, что практически повсеместно на Дальнем Востоке установилась практика занятия земель, основанная на "праве первого захвата (Jus primi ocucupandi)» [14, с. 12], когда каждый переселенец выбирал земли там, где хотел, и в том размере, в каком он желал. Русский крестьянин-поселенец «с самого начала видел себя окружённым... целым морем земли, кругом него был такой простор, от которого он давно уже отвык в европейской России» [14, с 13], что фактически предоставило ему моральное «право» занимать любой участок земли, руководствуясь только собственным усмотрением. В результате, незаконные земельные владения - заимки - чиновники сплошь и рядом обнаруживали в самых различных местностях края, причём даже в таких, которые искони считалась незаселёнными и даже неудобными для заселения.

Помимо изолированных заимок, разбросанных по всему краю, фрактически каждая более или менее заметная деревня в Сибири и на Дальнем Востоке, образовывала по всем направлениям целый ряд подобных незаконных владений, которые существовали и функционировали без какого-либо вмешательства со стороны государства. Как писал чиновник особых поручений при Переселенческом управлении МВД А.А. Риттих, находившийся в 1898-1899 гг. в командировке в Южно-Уссурийском крае, в деревнях, где было достаточно земли, не требующей особых предварительных трудов на обработку (осушение, корчевание), «каждая семья владела тем участком, который заняла - «заимкой»",, и никакого вмешательства общества в порядок пользования землёй не производилось. И в таком положении в 1899 г. находились, по его свидетельству, «91 деревня Южно-Уссурийского края из общего числа 102» [22, с. 47].

\section{Заимки и государство: нелегальное пользование землёй или эффективная колонизация окраины?}

Существование огромного числа нелегальных заимок, рассредоточенных по всей дальневосточной окраине, не было секретом для царских чиновников: их наличие констатировалось практически всеми, кто был знаком с переселенческим делом и жизнью дальневосточной окраины. Между тем, проблема существования незарегистрированных мест поселения фрактически не обращала на себя особого внимания царской администрации и зачастую обсуждалась в спокойных, непатетических тонах. Громадные территории Дальнего Востока представлялись всем настолько значительными, способными удовлетворить потребности в «удобной» земле как старожилов-заимочников, так и новых поселенцев, что многие, в особенности на первых порах, совершенно не видели оснований для решительного пресечения практики свободного пользования земельными богатствами края. Неслучайно, что межевые чины, отводившие участки для переселенцев, старались отграничивать переселен- 
ческий участок таким образом, чтоб обойти стороной наиболее крупные заимки, представляющие крепкие, развитые хозяйства, владельцы которых проживали здесь постоянно и фрактически порвали всякую связь с прежней деревней.

Куда более важными задачами по сравнению с выявлением и наказанием заимщиков считались заселение и колонизация российской окраины, а потому на случаи нелегального пользования землёй часто закрывали глаза, считая возможным таким способом содействовать естественному расселению народа по государственной территории. Именно поэтому на существовавшие в крае нелегальные формы землепользования зачастую смотрели сквозь пальцы. И этому во многом способствовало распространённое убеждение об обширности земель на востоке России, способных удовлетворить потребность в земле как старожилов, так и будущих поселенцев.

Небезынтересно, что при распространённости мнения о пустынности и малонаселённости дальневосточных земель, которое поддерживалось самим главноуправляющим землеустройством и земледелием при совете министров Столыпина - князем Б.А. Васильчиковым, отмечавшим, что «миллиард десятин земли Азиатской России представляет из себя пустыню, изобилующую всеми богатствами природы и бедную лишь одним - людьми» [Цит по: 4, с. 3], реальные размеры земельного фронда Дальнего Востока долгое время фрактически не были известны чиновникам. А.В. Кириллов, занимавшийся изучением переселенческого движения в Амурскую область и ставший в 1898 г. городским главой города Благовещенска, писал в 1895 г.: «До сих пор, несмотря на то, что уже проходит 35 год со времени появления в области первых переселенцев-земледельцев, ещё решительно ничего не сделано относительно приведения в известность земель как в количественном, так и в качественном отношении» $[\mathbf{1 1}$, с. 46]. И такое же заявление в полной мере могли бы разделить и некоторые другие $[2$, с. $2 ; 16$, с. $1 ; 7$, с. 171]. И хотя к началу ХХ в. в империи появились уже довольно авторитетные исследования, дававшие адекватную оценку плодородности дальневосточных земель и колонизационной вместимости края [См.: 8, 18], в общественно-политической риторике во многом продолжали господствовать представления о неисчерпаемости и безграничности тех перспектив, которые Дальний Восток открывал в плане переселения.

Головную боль царской администрации нелегальные заимки составляли лишь в том случае, когда становились причиной раздора в деревне или даже в нескольких соседних селениях. Возможность при попустительстве администрации безгранично выбирать по своему усмотрению земли к концу XIX столетия стала превращать целые деревни, а то и соседние посёлки во враждующие лагеря. И причиной тому оказывалось неравное положение поселенцев.

С годами прирост населения и потребность в земле новых поселенцев по-новому поставили вопрос о земельных «захватах». Неудовольствие наименее бедной части населения все чаще стали вызывать богатые владельцы заимок, сумевшие захватить в свои руки огромные пространства земли. Отдельные лица фрактически единолично «владели» обширными наделами в 200-300, а то и более десятин земли и, обрабатывая эти земли посредством наёмного труда, получали с них значительные прибыли, предоставляя повод для зависти наименее успешным односельчанам [22, с. 47]. Парадокс ситуации заключался в том, что при огромных размерах наделов старожилов, опоздавшие к разделу земли новопоселенцы вынуждены были довольствоваться гораздо более скромными земельными участками и даже покупать их у тех, кто водворился в деревне ранее и сумел воспользоваться «правом первого захвата». Не- 
равное положение переселенцев становилось причиной постоянных ссор и раздоров в деревне [См.: 16, с. 99; 17, с. 76; 22, с. 47]. Это дало повод А. Меньшикову, проводившему в 1910 г. экономико-статистическое исследование крестьянских хозяйств старожилов-стодесятинников в Амурском и Приморском крае, констатировать, что «заветная крестьянская мечта о «землице» осуществившись в праве на стодесятинный надел, казавшийся сперва безграничным, вылилась затем в уродливые фрормы захвата, пенкоснимание, в бесцельное и неразумное перескакивание с заимками с одного места на другое, включительно до продажи излишней и сверх нужды захваченной земли своему односельчанину, бесправие которого основывалось лишь на том, что он зачислился на надел позже продавца-первозахватчика» [16, с. 110].

Между тем, по свидетельству чиновников, конфрликты из-за земель имели место преимущественно в тех деревнях, где, несмотря на значительное пространство надела, начинал сказываться, благодаря быстрому росту посевной площади, недостаток чистых мест, пригодных для ведения сельского хозяйства или же где поблизости имелось манзовское или корейское население, ищущее работы и готовое довольствоваться низкой заработной платой. В большинстве же селений заимочное пользование не вызывало серьёзных неудовольствий: «право первого захвата» уважалось, а малоимущие крестьяне привыкли относиться к увеличению запашек зажиточных совершенно спокойно, полагая, что на их век хватит [22, с. 48].

В результате, заимочная система ведения хозяйства на Дальнем Востоке не особо занимала чиновников. Первостепенной задачей дальневосточной администрации было скорейшее заселение «бескрайних» просторов Сибири и Дальнего Востока и уплотнение населения здесь. И с этой точки зрения заимщики являлись скорее благом для региона, чем явлением сугубо отрицательного характера. И несмотря на тот фракт, что заимщиков часто критиковали за совершенно хищническое использование земель [22, с. 48], «пенкоснимание» [16, с. 110; 14, с. 13], а также видели в них определённую трудность при отведении участков для водворения новых поселенцев [7, с. 80], тем не менее, на образование нелегальных заимок в основном предпочитали смотреть сквозь пальцы.

\section{«...у них нет главного - они не русские»}

Интересно, однако, что при достаточно попустительском отношении к заимочной системе в районах Сибири и Дальнего Востока, тем не менее, земельные богатства края все же, по всей видимости, не считали достаточными для всех.

Помимо русских переселенцев на Дальнем Востоке нелегально селились также и иностранцы, в основном китайцы и корейцы. По замечанию Ф.Ф. Буссе, китайские франзы встречались в районе Южно-Уссурийского края «отдельными хуторами и в группах, иногда довольно обширных, во всех долинах незанятых русскими деревнями» и все они были «окружены пахотными полями, иногда на большой площади» [2, c. 18]. Подобная ситуация наблюдалась не только в Южно-Уссурийском крае, но и в других областях региона. Всюду переселенцы, следовавшие в указанные им места водворения, встречали разбросанные по всему региону китайские и корейские франзы [22, с. 6]. И если изначально при заселении региона фрактически не чинилось особых препятствий к их водворению в крае, поскольку в них видели возможность облегчить переселение русских на Дальний Восток (они могли обеспечить на первых порах поселенцев продуктами питания), то со временем поселение их в крае стало рассматриваться в качестве нежелательного и даже вовсе отрицательного явления. В 1886 г. был издан указ, согласно которому 
корейцам и китайцам было запрещено селиться в пограничных с Кореей и Китаем местах [22, с. 29], и, хотя эта мера имела под собой исключительно военно-стратегические основания, в некотором роде она отражала и общее отношение к заселению Дальнего Востока выходцами из Китая и Кореи.

Государственные чиновники, в большинстве случаев, смотревшие сквозь пальцы на нелегальную разработку больших площадей земли русскими и фрактически легализовавшие незаконный «захват» земель на окраине, тем не менее, довольно решительно сгоняли с мест китайцев и корейцев, незаконно водворившихся в регионе. Что же касается последних, то для них было «достаточно категорического указания администрации на предстоящий приход переселенцев», чтобы они «без противодействия уступили свои места» [22, с. 15]. Нельзя не отметить, однако, что подобное незаконное поселение китайского и корейского населения в регионе было даже выгодно чиновникам переселенческого управления - оно позволяло селить вновь прибывших на дальневосточную окраину русских переселенцев в местах, где уже были проведены все подготовительные мероприятия по расчистке почв, а это существенно облегчало водворение переселенцев в регионе. Эта мысль прямо выражалась в исследовании А. Меньшикова, писавшего, что при всей экономической малозначимости корейского хозяйства для региона, оно исключительно ценно для окраины в качестве «аванпоста заселения новых районов»: «Разработанный корейцами, этими своего рода «кочевыми земледельцами», уголок тайги становится базой дальнейшей колонизации, так как по проторённому корейцем пути идёт в тайгу и русский крестьянин» [16, с. 26].

Интересно, что совершенно различное отношение чиновники высказывали относительно китайского и корейского населения, нелегально селившегося на территории Дальнего Востока. И если китайцы считались элементом категорически неприемлемым для поселения в крае, способным в случае враждебного столкновения двух соседних империй оказать «своим сородичам помощь» [2, с. 19], то вот в отношении водворения корейцев однозначного мнения у чиновников не было. Корейцы смогли зарекомендовать себя в крае с положительной стороны, и им даже был выделен для поселения Посьетский участок, который после ряда исследований, был признан совершенно негодным для русской земледельческой культуры. Между тем, при рассмотрении вопроса о предоставлении возможности селиться в крае корейцам, к концу XIX в. пришли к выводу, что не стоит содействовать их водворению в регионе: «какими бы положительными качествами не обладали корейцы», по мнению чиновников переселенческого управления, «у них нет главного - они не русские» [22, с. 37].

Колонизовать край предполагалось исключительно русским элементом. О чем открыто заявлялось в официальных документах: «политическая цель заключается в противопоставлении жёлтому человеку белого, в нравственном экономическом и даже фризическом отношениях... этим требованиям соответствуют все русские подданные, какого бы происхождения они не были и потому привлечение их в край было бы тем полезнее, что такое приращение населения не вызывает расходов правительства, мало того приносит с собою капитал, энергию и умственный труд» (РГИА. Ф. 391. Оп. 1. Д. 24. Л. 68). В результате, на российской окраине было достаточно земель, чтоб не замечать нелегальные захваты, но только при условии того, что эти нелегальные пользователи земли были бы русскими подданными. 


\section{***}

Дальневосточные земли, присоединённые к России лишь во второй половине XIX в., совершенно по-новому поставили вопрос об отношении к земле и земельным богатствам в империи. В отличие от территорий европейской России, где фрактически вся земля была точно определена в своих границах и зачастую имела своего владельца, на дальневосточной окраине ситуация была прямо противоположной. Огромный земельный простор формировал здесь восприятие земли в качестве свободного дара природы, не имеющего своего законного собственника. Такие убеждения позволяли значительной массе жителей окраины фрактически свободно выбирать землю в своё пользование, не согласуясь с мнением местной администрации. Парадоксальным образом такая система существовала при полной осведомлённости государственных чиновников, особо не пытавшихся защитить государственное имущество от незаконных захватов и образования нелегальных заимок. И если в европейской части России захватом считалось уже скашивание пограничной полосы соседнего владения [См.: 5; 6; 11], на просторах российского Дальнего Востока разработка даже обширных земельных угодий практически не вызывала серьёзных возражений чиновников: обширность дальневосточных земель позволяла здесь довольно снисходительно относиться к распашкам огромных площадей, полагая, что земли хватит на всех желающих. На российской окраине собственно и понимание самого захвата было совершенно иным: здесь в попустительстве захватам видели ещё и возможность дать новоиспечённым жителям региона успешно освоиться в новой для себя обстановке, завести крепкое хозяйство. И, хотя к началу XX в., стали наблюдаться некоторые попытки чиновников сократить число незаконных захватов с помощью ряда административных мер [16, с. 101], тем не менее решительного пресечения практики захватного землепользования так и не произошло.

\section{Литература}

1. Белянин Д.Н. Предпосылки и характер индивидуализации крестьянского землевладения в Западной Сибири в начале XX в. // Вестник Кузбасского государственного технического университета. 2005. № 1 (38). C. $120-126$.

2. Буссе Ф.Ф. Переселение морем в Южно-Уссурийский край в 1883-1893. СПб.: тип. Общественная польза, 1896. 57 с.

3. Гарбуз И.В. Земельные отношения в Забайкальской области во второй половине XIX в. // Гуманитарный вектор. 2011. № 3. С. 31-39.

4. Гинс Г. Переселение и колонизация. Оттиск из вопросов колонизации. № 12. СПб.: тип. Ф. Вайсберга и П. Гершунина, 1913. 65 с.

5. Гузей Я.С. К вопросу о захватном землепользовании в европейской части Российской империи во второй половине XIX - начале XX вв. // Вестник Томского государственного университета. История. 2017. № 45. С. 5-10.

6. Земельные захваты и межевое дело. Особое совещание о нуждах сельскохозяйственной промышленности. Свод трудов местных комитетов по 49 губерниям европейской России / Сост. С.И. Шидловский. СПб.: тип. В.Ф. Киршбаума, 1904. 171 с. 
7. Исаев А.А. Переселение в русском народном хозяйстве. СПб.: изд. А.Ф. Цинзерлинга, 1891. 192 с.

8. Кауфман А.А. Материалы по вопросу о колонизационной вместимости Приамурского края. СПб.: тип. В.Ф. Киршбаума, 1901. 298 с.

9. Кауфман А.А. Переселение и колонизация. СПб.: тип. Общественная польза, 1905. 349.

10. Каширина И.Б., Лепехин А.В., Титова А.Д. Формирование и развитие системы расселения в Амурской области: начало (1857-1889 гг.) // Вестник Амурского государственного университета. 2015. № 68. С. 16-21.

11. Кириллов А. Переселения в Амурскую область // Труды Приамурского отдела императорского русского географического общества. Хабаровск, 1895. $47 \mathrm{c.}$

12. Крестьянское землепользование. Особое совещание о нуждах сельскохозяйственной промышленности. Свод трудов местных комитетов по 49 губерниям европейской России / Сост. А.А. Риттих. СПб.: тип. В.Ф. Киршбаума, 1903. $117 \mathrm{c}$.

13. Крестьянство Дальнего Востока СCCP (XIX-XX вв.): сб. статей / Под ред. А. И. Крушанова. Владивосток, 1979. 142 с.

14. Крюков Н.А. Опыт описания землепользования у крестьянпереселенцев Амурской и Приморской областей // Записки Приамурского отдела императорского русского географрического общества. М.,1896. Т 2. Вып. 2. С. 1-122.

15. Ландарь И.А. Аграрная политика государства в отношении казачества восточных окраин России на рубеже XIX - XX веков // Власть и управление на Востоке России. 2010. № 2 (51). С. 195-199.

16. Материалы по обследованию крестьянских хозяйств Приморской области. Старожилы-стодесятинники. Том III (текст). / Составил А. Меньщиков. Под ред. А.А. Татищева. Саратов, 1912. 505 с.

17. Материалы по обследованию крестьянских хозяйств Приморской области. Старожилы-стодесятинники. Toм IV (описание селений). / Составил А. Меньщиков. Под ред. А.А. Татищева. Саратов, 1912.575 с.

18. Надаров И. Второй Хабаровский съезд 1886 года. Владивосток, 1886.

19. Польская Е.В. К вопросу о захватном землевладении на Дальнем Востоке во второй половине XIX - начале XX // Наука и образование в жизни современного общества: сб. науч. трудов. Тамбов, 2012. № 2012. С. 122-123.

20. Польская Е.В. Землевладение и землепользование казаков на Дальнем Востоке во второй половине XIX - начале XX вв. // Вектор науки ТГУ. 2014. № 2(28). C. 119-121.

21. Польская Е.В., Стасюкевич С.М. Частная собственность на землю на Дальнем Востоке России во второй половине XIX - начале XX в. // Вестник Ленинградского государственного университета им. А.С. Пушкина. 2012. Т. 4. № 3. C. 91-101.

22. Риттих А.А. Переселенческое и крестьянское дело в Южно-Уссурийском крае. Отчёт по командировке чиновника особых поручений Переселенческого управления А.А. Риттиха. СПб., 1899. 154 с.

23. Сафронов С.А. Поиски земель в Сибири, пригодных для колонизации в конце XIX в. // Наука и современность. Новосибирск, 2012. С. 63-67.

24. Татарникова А.И. Взаимосвязь типов сельских поселений и характера землепользования в Западной Сибири во второй половине XIX - начале XX вв. // Современная наука агропромышленному производству. Тюмень, 2014. C. $145-148$.

25. Masoero Alberto. Layers of property in the tsar's settlement colony: projects of land privatization in Sibiria in the late nineteenth century // Central Asian Survey. 2010. Vol. 29. № 1. P. 9-32. 


\section{Транслитерация по ГОСТ 7.79-2000 Система Б}

1. Belyanin D.N. Predposylki i kharakter individualizatsii krest'yanskogo zemlevladeniya v Zapadnoj Sibiri v nachale XX v. // Vestnik Kuzbasskogo gosudarstvennogo tekhnicheskogo universiteta. 2005. № 1 (38). S. 120-126.

2. Busse F.F. Pereselenie morem v YUzhno-Ussurijskij kraj v 1883-1893. $\mathrm{SPb} .:$ tip. Obshhestvennaya pol'za, 1896. $57 \mathrm{~s}$.

3. Garbuz I.V. Zemel'nye otnosheniya v Zabajkal'skoj oblasti vo vtoroj polovine XIX v. // Gumanitarnyj vektor. 2011. № 3. S. 31-39.

4. Gins G. Pereselenie i kolonizatsiya. Ottisk iz voprosov kolonizatsii. № 12. SPb.: tip. F. Vajsberga i P. Gershunina, 1913. 65 s.

5. Guzej YA.S. K voprosu o zakhvatnom zemlepol'zovanii v evropejskoj chasti Rossijskoj imperii vo vtoroj polovine XIX - nachale XX vv. // Vestnik Tomskogo gosudarstvennogo universiteta. Istoriya. 2017. № 45. S. 5-10.

6. Zemel'nye zakhvaty i mezhevoe delo. Osoboe soveshhanie o nuzhdakh sel'skokhozyajstvennoj promyshlennosti. Svod trudov mestnykh komitetov po 49 guberniyam evropejskoj Rossii / Sost. S.I. SHidlovskij. SPb.: tip. V.F. Kirshbauma, 1904. 171 s.

7. Isaev A.A. Pereselenie v russkom narodnom khozyajstve. SPb.: izd. A.F. TSinzerlinga, 1891. $192 \mathrm{s.}$

8. Kaufman A.A. Materialy po voprosu o kolonizatsionnoj vmestimosti Priamurskogo kraya. SPb.: tip. V.F. Kirshbauma, 1901. 298 s.

9. Kaufman A.A. Pereselenie i kolonizatsiya. SPb.: tip. Obshhestvennaya pol'za, 1905. 349.

10. Kashirina I.B., Lepekhin A.V., Titova A.D. Formirovanie i razvitie sistemy rasseleniya v Amurskoj oblasti: nachalo (1857-1889 gg.) // Vestnik Amurskogo gosudarstvennogo universiteta. 2015. № 68. S. 16-21.

11. Kirillov A. Pereseleniya v Amurskuyu oblast' // Trudy Priamurskogo otdela imperatorskogo russkogo geograficheskogo obshhestva. KHabarovsk, 1895. $47 \mathrm{~s}$.

12. Krest'yanskoe zemlepol'zovanie. Osoboe soveshhanie o nuzhdakh sel'skokhozyajstvennoj promyshlennosti. Svod trudov mestnykh komitetov po 49 guberniyam evropejskoj Rossii / Sost. A.A. Rittikh. SPb.: tip. V.F. Kirshbauma, 1903. $117 \mathrm{~s}$.

13. Krest'yanstvo Dal'nego Vostoka SSSR (XIX-XX vv.): sb. statej / Pod red. A. I. Krushanova. Vladivostok, 1979. 142 s.

14. Kryukov N.A. Opyt opisaniya zemlepol'zovaniya u krest'yan-pereselentsev Amurskoj i Primorskoj oblastej // Zapiski Priamurskogo otdela imperatorskogo russkogo geograficheskogo obshhestva. M.,1896. T 2. Vyp. 2. S. 1-122.

15. Landar' I.A. Agrarnaya politika gosudarstva $\mathrm{v}$ otnoshenii kazachestva vostochnykh okrain Rossii na rubezhe XIX - XX vekov // Vlast' i upravlenie na Vostoke Rossii. 2010. № 2 (51). S. 195-199.

16. Materialy po obsledovaniyu krest'yanskikh khozyajstv Primorskoj oblasti. Starozhily-stodesyatinniki. Tom III (tekst). / Sostavil A. Men'shhikov. Pod red. A.A. Tatishheva. Saratov, 1912. 505 s.

17. Materialy po obsledovaniyu krest'yanskikh khozyajstv Primorskoj oblasti. Starozhily-stodesyatinniki. Tom IV (opisanie selenij). / Sostavil A. Men'shhikov. Pod red. A.A. Tatishheva. Saratov, 1912. 575 s.

18. Nadarov I. Vtoroj KHabarovskij s"ezd 1886 goda. Vladivostok, 1886.

19. Pol'skaya E.V. K voprosu o zakhvatnom zemlevladenii na Dal'nem Vostoke vo vtoroj polovine XIX - nachale XX // Nauka i obrazovanie v zhizni sovremennogo obshhestva: sb. nauch. trudov. Tambov, 2012. № 2012. S. 122-123.

20. Pol'skaya E.V. Zemlevladenie i zemlepol'zovanie kazakov na Dal'nem Vostoke vo vtoroj polovine XIX - nachale XX vv. // Vektor nauki TGU. 2014. № 2(28).

S. $119-121$.

21. Pol'skaya E.V., Stasyukevich S.M. CHastnaya sobstvennost' na zemlyu na Dal'nem Vostoke Rossii vo vtoroj polovine XIX - nachale XX v. // Vestnik 
Leningradskogo gosudarstvennogo universiteta im. A.S. Pushkina. 2012. T. 4. № 3. S. 91-101.

22. Rittikh A.A. Pereselencheskoe i krest'yanskoe delo v YUzhno-Ussurijskom krae. Otchyot po komandirovke chinovnika osobykh poruchenij Pereselencheskogo upravleniya A.A. Rittikha. SPb., 1899. $154 \mathrm{~s}$.

23. Safronov S.A. Poiski zemel' v Sibiri, prigodnykh dlya kolonizatsii v kontse XIX v. // Nauka i sovremennost'. Novosibirsk, 2012. S. 63-67.

24. Tatarnikova A.I. Vzaimosvyaz' tipov sel'skikh poselenij i kharaktera zemlepol'zovaniya v Zapadnoj Sibiri vo vtoroj polovine XIX - nachale XX vv. // Sovremennaya nauka agropromyshlennomu proizvodstvu. Tyumen', 2014. S. 145148.

25. Masoero Alberto. Layers of property in the tsar`s settlement colony: projects of land privatization in Sibiria in the late nineteenth century // Central Asian Survey. 2010. Vol. 29. № 1. P. 9-32. 